\title{
The H2020 FREEWAT participated approach for the Follonica-Scarlino aquifer case study. A common space to generate shared knowledge on the value of water
}

\section{L'esperienza dell'approccio partecipato del progetto H2020 FREEWAT al caso studio di Follonica-Scarlino. Uno spazio comune per generare conoscenza condivisa sul valore dell'acqua}

Pio Positano, Marco Nannucci

\begin{abstract}
Riassunto: Il caso studio dell'acquifero di Follonica-Scarlino è stato condotto da Regione Toscana, nell'ambito del progetto H2020 FREEWAT, quale partner di un consorzio internazionale creato ad hoc. FREEWAT mira a promuovere la gestione delle risorse idriche semplificando l'applicazione della direttiva quadro sulle acque e di altre direttive comunitarie relative all'acqua. Lo strumento utilizzato per raggiungere questo obiettivo è un ambiente di modellazione numerica open source integrato col GIS per simulazioni di quantità e qualità nelle acque superficiali e sotterranee. L'area di studio è situata nella omonima pianura costiera che si trova nella parte meridionale della Toscana. Il sistema acquifero di questa pianura è influenzato da varie problematiche, ma il modello numerico creato tramite la piattaforma FREEWAT è stato utilizzato per studiare in particolare il problema di sovrasfruttamento della falda. Il deficit di quantità della risorsa idrica è dovuto principalmente ai prelievi industriali e agricoli molto consistenti ma è di notevole quantità anche il prelievo per l'approvvigionamento idrico civile durante la stagione estiva. L'approccio partecipativo, incluso nel progetto FREEWAT, è stato fondamentale per raccogliere e sistematizzare l'enorme quantità di dati sul sistema acquifero e per creare conoscenza condivisa sulla risorsa idrica. Attraverso sette focus group i vari attori locali hanno raggiunto un accordo sugli scenari da esplorare con la piattaforma FREEWAT. I focus group da 1 a 3 sono stati utilizzati per identificare gli obiettivi del caso studio mentre i focus group da 4 a 6 hanno permesso di indivi-
\end{abstract}

Keywords: Follonica, Scarlino, numerical modeling, participatory approach, SWOT Analysis.

Parole chiave: Follonica, Scarlino, groundwater, modellazione numerica, approccio partecipato, SWOT Analysis.

Pio POSITANO 莑:

Direzione urbanistica e politiche abitative - Regione Toscana

Via di Novoli 26, Firenze

pio.positano@regione.toscana.it

\section{Marco NANNUCCI}

Direzione Ambiente ed Energia - Regione Toscana

Via San Gallo, Firenze

marco.nannucci@regione.toscana.it

Ricevuto/Received: 21 August 2017-Accettato/Accepted: 18 September 2017 Pubblicato online /Published online: 30 September 2017

This is an open access article under the CC BY-NC-ND license:

http://creativecommons.org/licenses/by-nc-nd/4.0/

(C) Associazione Acque Sotterranee 2017 duare il problema della gestione dell'acqua e selezionare lo scenario da modellizzare. La comunità degli stakeholders ha scelto due dei quattro scenari risultanti dalle riunioni del focus group. Entrambe le simulazioni hanno dimostrato, attraverso il supporto numerico del motore di modellazione numerica e il supporto grafico del GIS, l'efficacia delle soluzioni tecniche proposte per il conseguimento degli obiettivi stabiliti nel piano di gestione dei bacini idrografici. Alla fine del percorso partecipato il gruppo di lavoro ha fornito utili suggerimenti e feedback per una nuova modalità di gestione delle risorse idriche. Inoltre alcuni ingegneri delle industrie locali hanno mostrato interesse a utilizzare la piattaforma open source FREEWAT come strumento di modellazione per il loro lavoro, partendo dal modello numerico prodotto da questo caso di studio per elaborare nuove implementazioni.

Abstract: The "Follonica-Scarlino Aquifer" case study is run within the H2020 FREEWAT project by Regione Toscana as partner of an international consortium. FREEWAT aims at promoting water resource management by simplifying the application of the Water Framework Directive and other EU water related Directives. The tool used to reach this target is an open source and public domain GIS integrated modeling environment for the simulation of water quantity and quality in surface water and groundwater. The case study area is located in a coastal plain in the Southern part of Tuscany (Italy) and the aquifer system is affected by various issues: in particular, the numerical model created through FREEWAT platform was used to study the problem of aquifer over-exploitation. The deficit in quantity of the water resource is mainly caused by the buge industrial and agricultural abstractions, but drinking water supply during the summer season is also notable. The participatory approach, included in the FREEWAT project, became of crucial importance to gather the huge amount of data about the aquifer system and to create a shared knowledge about water resource. It was carried out through seven focus groups and led the stakeholders to reach an agreement about the scenarios to be explored with FREEWAT software platform. Focus Group 1 to 3 were used to identify the case study objectives. Focus Groups 4 to 6 allowed to assess the water management issues and select the scenarios. The community chose two of the four scenarios that came out from the focus group meetings. Simulations corresponding to these two scenarios have shown, the effectiveness of the proposed technical solutions for achieving the objectives set out in the River Basin Management Plan of the Northern Apennines District. At the end of the focus group cycle, useful suggestions and feedbacks came from stakebolders, to set up a new kind of water management. Some experts working for local industries expressed their interest in using the FREEWAT open source platform as professional modeling tool. 


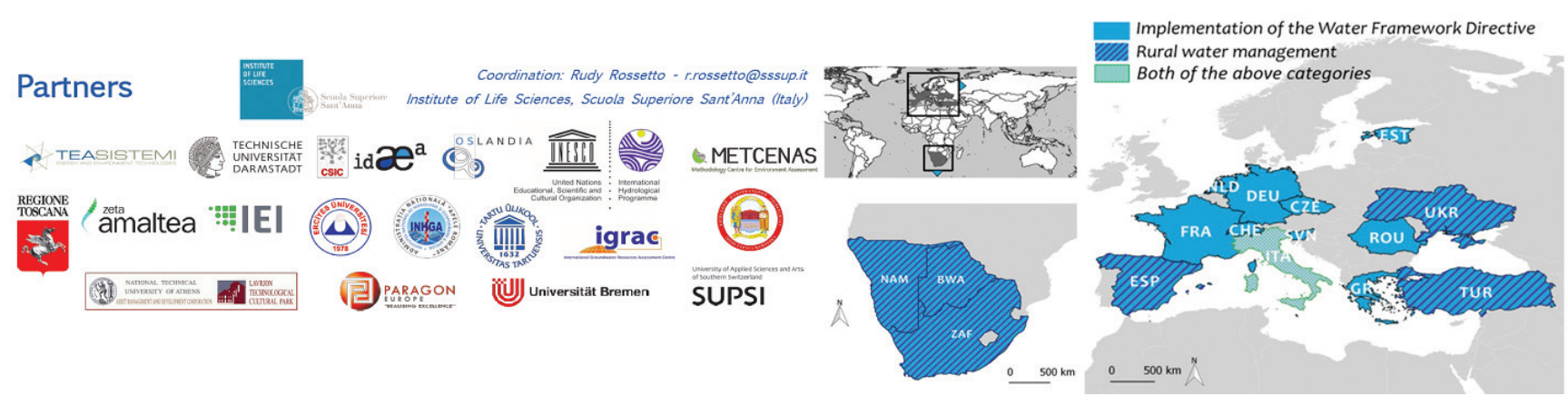

Fig. 1 - The FREEWAT Consortium (19 partners, 9 case studies for application of the WF Directive, 5 case studies for rural water management, more that 220 institutions involved, more than 600 people trained so far.

Fig. 1 - Il consorzio FREEWAT (19 partners, 9 casi di studio per l'applicazione della WF Directive, 5 casi di studio per la gestione delle acque in ambiente rurale, più di 220 istituzioni coinvolte, più di 600 persone formate fino ad ora).

\section{Introduction}

The "Follonica-Scarlino Aquifer" case study is run within the FREEWAT project by Regione Toscana, the governing authority in Tuscany. FREEWAT is an HORIZON 2020 project financed by the EU Commission under the call WATER INNOVATION: BOOSTING ITS VALUE FOR EUROPE (Fig. 1). The project aims at promoting water resource management by simplifying the application of the Water Framework Directive and other EU water related Directives through the use of an open source and public domain GIS integrated modeling environment with a water management and planning module (the FREEWAT platform), for the simulation of water quantity and quality in surface water and groundwater.

The FREEWAT platform can produce numerical models and scenarios helping decision and policy makers to get scientifically and technically sound solutions, based on data and on a participatory approach which involves the stakeholders during the phase of River Basin Management Plan (RBMP) definition.

\section{The case study}

The case study area of Follonica-Scarlino is located in the south part of Tuscany in a coastal plain at the end of the Pecora River valley (Fig. 2). This area belongs to the "Colline Metallifere" pyrite-base metals district. Since the EtruscanRoman times until present days, it was exploited for various mining and metallurgical activities.

The Follonica-Scarlino aquifer system is one of the groundwater reservoirs characterized and defined by the Region of Tuscany under the EU Water Framework Directive 2000/60/EC, through a multidisciplinary geological, hydrogeological and geochemical approach (Delibera Giunta Regione Toscana n. 939/2009). Many other data about the aquifer were collected during a further regional project called GEOBASI (ARPAT, LaMMa Consortium, IGG-CNR, Regione Toscana, University of Florence, University of Pisa, University of Siena) (Raco et al. 2015).

The study area is affected by various issues: the numerical model created with FREEWAT platform was focused to study the aquifer over-exploitation problem, according to the
Programme of Measures of the River Basin Management Plan compiled by Northern Apennines District Authority (RBMP Programme of Measures 2010), in compliance with the EU WFD 2000/60/EC.

The deficit in quantity of the resource is mainly caused by the huge industrial and agricultural withdrawals, but civil water supply during the summer season is also notable, as the population of the area grows up to ten times more, during the touristic season (Comune di Follonica 2014).
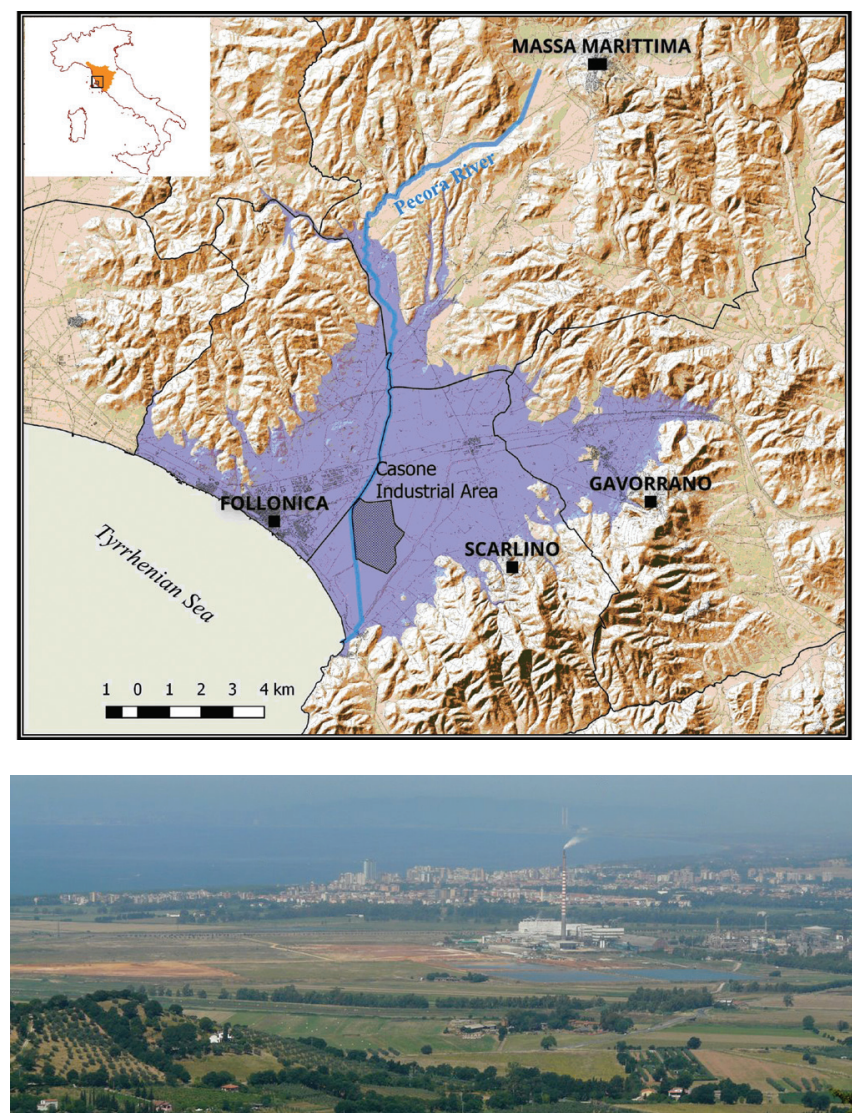

Fig. 2 - The case study area.

Fig. 2 - L' area del caso di studio. 


\section{The aquifer model}

The application of the FREEWAT platform to the FollonicaScarlino aquifer led to obtain a groundwater flow numerical model based on a solid conceptual model of the aquifer system elaborated on the analysis of the huge amount of geological, hydro-geological and geochemical data. The system is a multi-layer aquifer made by eight aquifer bodies, but only
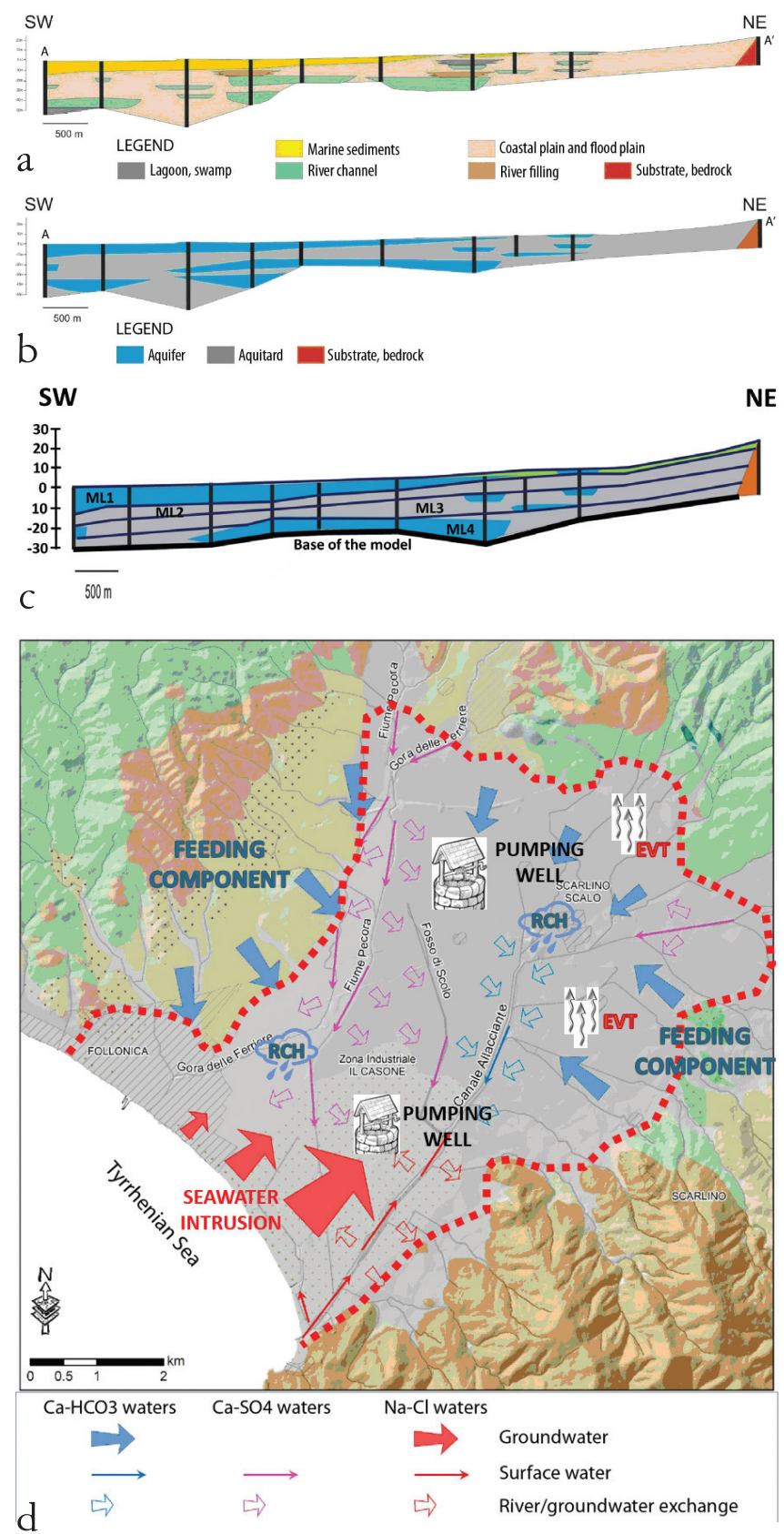

Fig. 3 - Cross section of the hydrostratigraphic (a) and hydrogeological (b) model (from Aurilio, 2016, modified; c) simplified sketch of model vertical discretization (blue: aquifer; grey: aquiclude); d) bydrogeologic schema of Follonica-Scarlino coastal plain (from Dalle Luche 2016, modified).

Fig. 3 - Sezione del modello idrostratigrafico (a) e idrogeologico (b) (da Aurilio, 2016, modificato; c) disegno semplificato della discretizzazione verticale del modello (blue: acquifero; grigio: acquicludo); d) schema idrogeologico della pianura costiera di Follonica-Scarlino (da Dalle Luche 2016, modificato). the upper five are more extended and sufficiently known. The system is mainly characterized by low permeability materials (clay and silty clay) where aquifers with medium-high permeability (from silty sand to sandy gravel) are present. The permeability value and the presence of many multiscreen wells should exclude the presence of a confined aquifer, except for local areas. The Follonica-Scarlino system seems to be fed from the aquifers hosted in the surrounding hills and the related surface water, as evidenced by hydrogeological and geochemical data elaborations. It is also fed by meteoric local infiltration and river seepage. In particular, the rivers in some cases act with a feeding component, in other cases drain the aquifer (see river/groundwater exchange arrows directions in figure $3 \mathrm{~d}$ ).

The numerical groundwater flow model for the FollonicaScarlino aquifer was implemented using the MODFLOW-2005 code (Harbaugh, 2005) through the FREEWAT interface. The whole extension of the Follonica-Scarlino plain was identified as the active domain and the aquifer system was sketched in four model layers, based on the hydraulic parameters and the continuity and extension of the layers along the basin (Figs. 3 and 4). Each layer was discretized horizontally in $100 \mathrm{~m}$ x 100 $\mathrm{m}$ cells, for a total of 110 rows and 109 columns.

The simulation time was divided in 25 stress periods: the first one in a steady-state condition (2009) with a length of 1 year, while the other periods are transient, each one 3 months long, for a total of 6 years (2005-2010).

The hydraulic parameters (hydraulic conductivity, specific yield, specific storage) assigned to each cell were calculated considering literature data and the lithology of the horizons, reconstructed in the conceptual model. These values were then modified during the calibration phase.

As boundary conditions, a Constant Head was applied along the coast line (set to $0 \mathrm{~m}$ a.s.l) whereas at the borders of the active domain, a General Head Boundary was applied just where the conceptual model indicates a feeding inflow component. The others cells of the boundaries were set as noflow. The value of hydraulic head was varied in each different season with a maximum annual variation of $1 \mathrm{~m}$ for transient state simulation.

The recharge to the aquifer was applied at layer 1 as effective infiltration rate, using the Recharge package in MODFLOW. To obtain an effective rainfall for each stress period of simulation, the evapotranspiration value, estimated by using Turc equation (1954), was subtracted from the gross rainfall measured. At this value was applied a potential infiltration coefficient of $0.4 \%$, for urban areas and a value of $0.5 \%$ for rural areas. The domestic withdrawal was implemented like negative recharge, homogeneously distributed in the urban area, depending on the number of wells per surface unit. This process led to have 7 recharge zones.

The main rivers and the artificial drainage canals of the basin were modeled using respectively the River and the Drain package of MODFLOW. For the river head we used, when available, the value recorded by the automatic monitoring station of the Region of Tuscany, located in the 
area of interest. For values of riverbed bottom and width, we used the data of the LIDAR image of the Region of Tuscany.

The WELL package in MODFLOW was used for wells differing from the domestic ones, which were simulated using a negative recharge. Each well was considered active in the layer of interest considering the depth and the well development. The flow-rate for steady-state and transientstate simulation was changed according to the data coming from different stakeholders, basing on the different use of the water resource (drinking water, agricultural or industrial). The initial condition of head for the steady-state was above the topographic elevation.

The numerical solver used in MODFLOW was the PCG, with 100 outer interaction and 50 inner interaction. For the other parameters we used the default value of the of FREEWAT interface. To calibrate the model the trial-anderror method was used in order to identify a set of parameters that produce a satisfactory match to the field observation with the simulated value. Input parameters which have been mainly modified in sequential run of the model until the model produce an acceptable match, are the hydraulic parameter of the layer, the hydraulic parameter of the river sediment and the river head (see Fig. 4 and Table 1). The hydraulic parameters of the river sediment were implemented with an order of magnitude less.

The groundwater head data collected during June 2014 were used as calibration target of the steady-state simulation. The piezometric map based on these data, the output of the steady state simulation and simulated data versus observed value are reported in Figure 5.
Tab. 1 - Zone and value of Hydraulic conductivity $(\mathrm{m} / \mathrm{s})$ assigned to the cell of the model pre and post calibration, based on stratigraphy grain size and hydrostructural model.

Tab. 1 - Zona e valore della conduttività idraulica $(\mathrm{m} / \mathrm{s})$ assegnata alla cella del modello pre and post calibrazione, sulla base di dati granulometrici e stratigrafici e sul modello idrostrutturale.

\begin{tabular}{|c|c|c|c|}
\hline Zone & Horizon & $\begin{array}{c}\text { K }(\mathrm{m} / \mathrm{s}) \text { from } \\
\text { grain size }\end{array}$ & $\begin{array}{c}\text { K }(\mathrm{m} / \mathrm{s}) \text { post } \\
\text { calibration }\end{array}$ \\
\hline 1 & 75 & $1.16 \mathrm{E}-05$ & $1.16 \mathrm{E}-05$ \\
\hline 2 & 70 & $2.31 \mathrm{E}-05$ & $5.79 \mathrm{E}-05$ \\
\hline 3 & 65 & $5.79 \mathrm{E}-07$ & $1.16 \mathrm{E}-06$ \\
\hline 4 & $60 \_50 \_40$ & $3.47 \mathrm{E}-04$ & $2.89 \mathrm{E}-04$ \\
\hline 5 & $55 \_45$ & $2.31 \mathrm{E}-06$ & $1.16 \mathrm{E}-05$ \\
\hline
\end{tabular}

From the water budget of the steady-state simulation the main feeding component of the system are the recharge and the inflow from the boundary condition (northwestern and eastern area) according to the conceptual model. The seepage from the rivers is also an important feeding component. The output from the system occurs mainly by wells.

The simulation made in steady-state condition, represents the average budget on annual basis. Since the maximum drinking water supply is during summer, a transientstate model simulation was done in low groundwater level condition for the three summer months (July - September) (Figs 10 and 11). To better evaluate the effectiveness of the RBMP measure for the Scenario 0 simulation and the effectiveness of the mine drainage water reuse solution for the Scenario 3, a transient-state simulation was performed, even if data for calibration were very poor. There is indeed only one
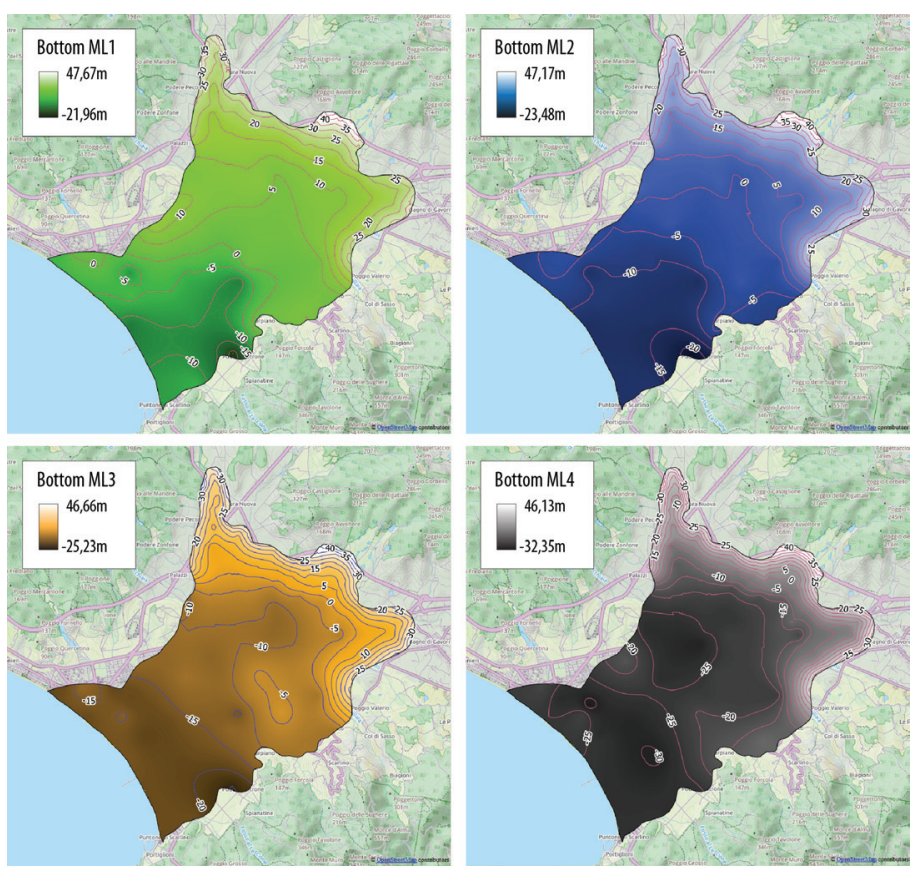

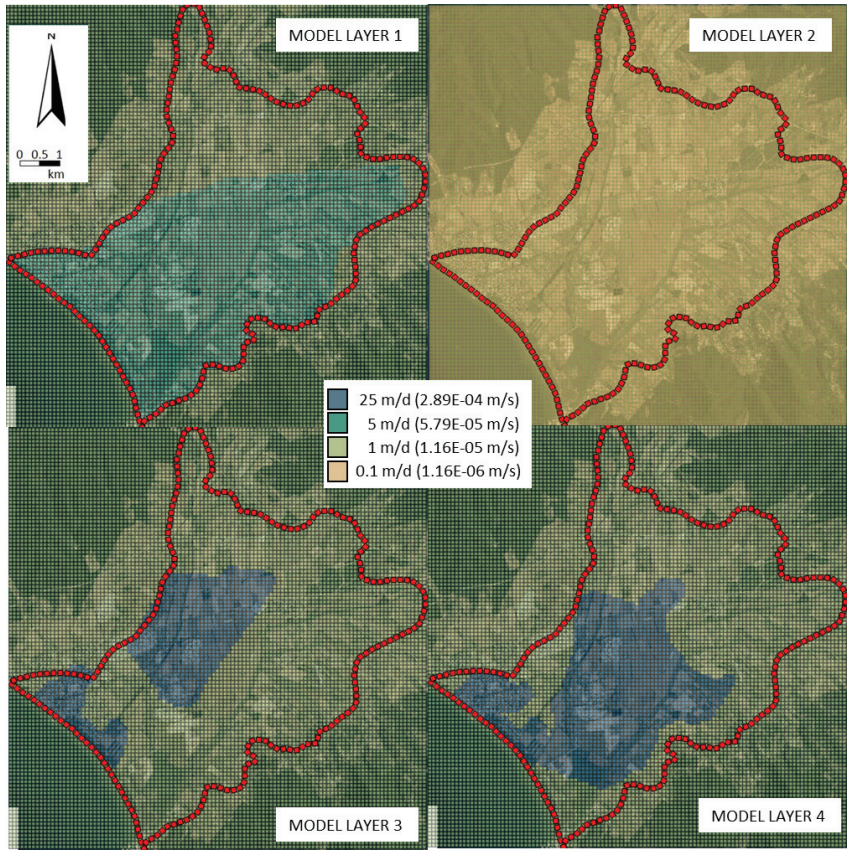

Fig. 4 - On the left: bottom values of the four Model Layers. On the right: hydraulic conductivity of each model layer assigned post calibration.

Fig. 4 - A sinistra: valori della superficie di letto dei quattro strati del modello. A destra: conduttività idraulica per ogni strato del modello, assegnata dopo la calibrazione. 


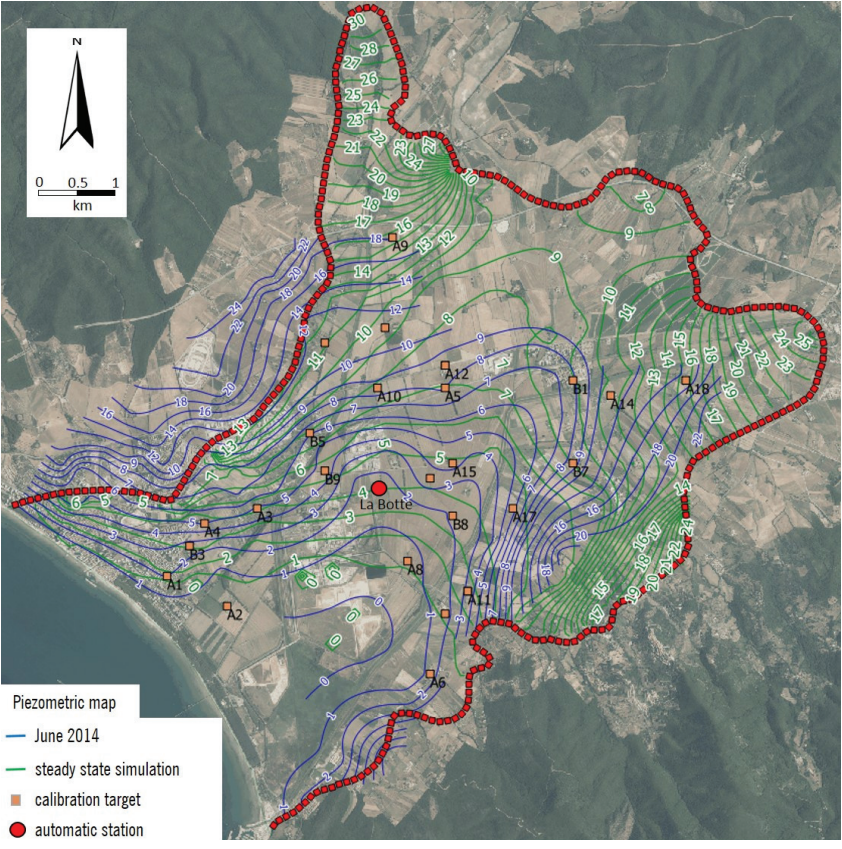

automatic station recording groundwater level and is located in the central part of the case study area, mainly positioned in the first aquifer (layer 1) at about $9.5 \mathrm{~m}$ of depth. Registered data versus simulated values of groundwater head at the "La Botte" automatic station (see the red dot in figure 5) shows an important variability in the different season. This highlights the importance to have additional automatic stations located in different strategic points of the basin to obtain a good calibration of the model in transient state to make a better assessment of the effectiveness of the simulation solutions.

\section{The participatory approach}

The numerical model, is able to forecast the response of the aquifer system to different solicitations and changes in the water balance simulating different scenarios. According to

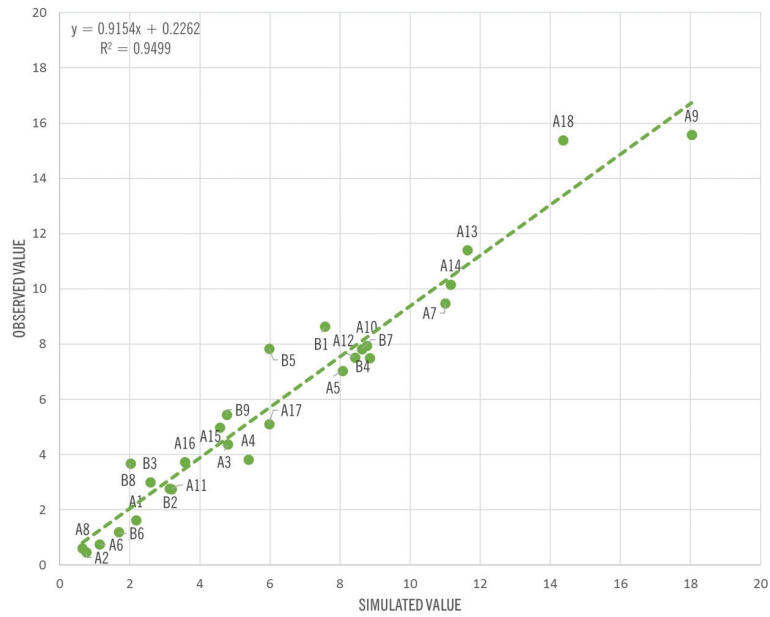

Fig. 5 - Piezometric map in June 2014 and groundwater head simulated in steady-state condition. In the lower part, observed vs simulated values for the groundwater head measured in June 2014.

Fig. 5 - Mappa piezometrica a giugno 2014 e carico idraulico simulato in condizioni stazionarie. Nella parte inferiore, i valori osservati rispetto a quelli simulati per il carico idraulico misurato a giugno 2014.

the problem and to the target water policy, the case study was useful to investigate various design solutions to increase the quantity of the water resource and to provide a reliable support to decision makers through the participatory approach of the H2020 FREEWAT project.

Seven focus groups led the stakeholders to reach an agreement about scenarios to be explored with FREEWAT software platform.

The whole focus group participatory approach can be divided in three blocks depending on their objective (Fig. 6). In the first block (from Focus Group 1 to 3 ) the stakeholders have been involved to identify the case study objectives. The second part aimed at targeting the case study water management issues (from Focus Group 4 to 6) while the final part (Focus Group 7) was dedicated to summarize the results and to collect feedbacks.

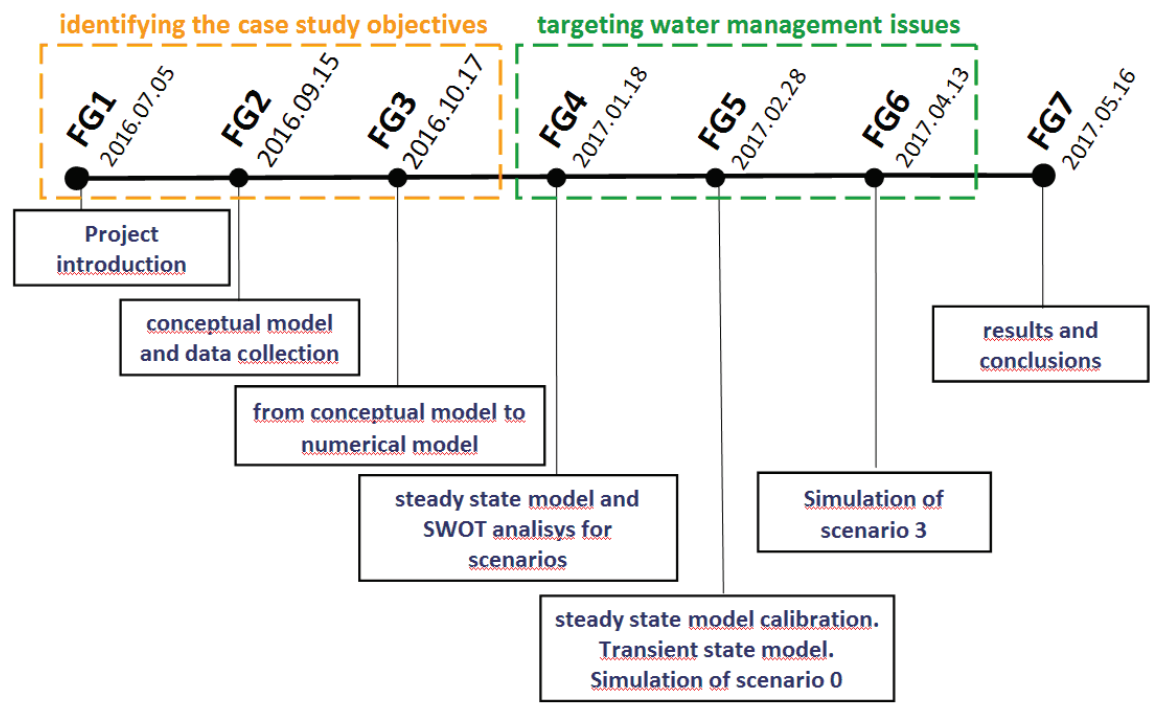

Fig. 6 - Focus Group time scheduling with arguments. The meetings were grouped by participatory objective.

Fig. 6 - Calendario dei Focus Group e relativi argomenti trattati. Gli incontri sono stati raggruppati sulla base degli obbiettivi legati al percorso partecipativo. 


\section{Focus Groups 1-3: identifying the case study objectives}

Firstly, we needed to understand how water management issue was perceived in the study area and how much the stakeholders believed that new technologies could improve water management. Since water and pollution management issues are very controversial in the case study area from long time, initially we needed to avoid any possible misunderstanding about the commitment of the project team as members of a public institution. The Region of Tuscany is already engaged in this area in remediation works in relationships with local authorities, institutions and private stakeholders about these topics. This approach has been useful to create a collaborative climate within the working group and to reach a shared awareness of the available data set in order to build the numerical model. The first effect of this good social climate was that the involved stakeholders provided themselves the missing data set for the numerical model.

Due to the strong interest for this new study in such a "hot" area, the group was very wide (20 -25 people) at the beginning (focus group 1, 2 and 3; Fig. 7), much more than a focus group has to be in order to have a good result on the arguments of discussions. The group was composed by various kinds of participants interested in knowing about the FREEWAT project and the number of attendees changed from a meeting to another. In particular, a group of them, from seven to ten people, took part to almost all the seven meetings and was the core of the focus group. Among the components of the group along the seven appointments, we can find: local
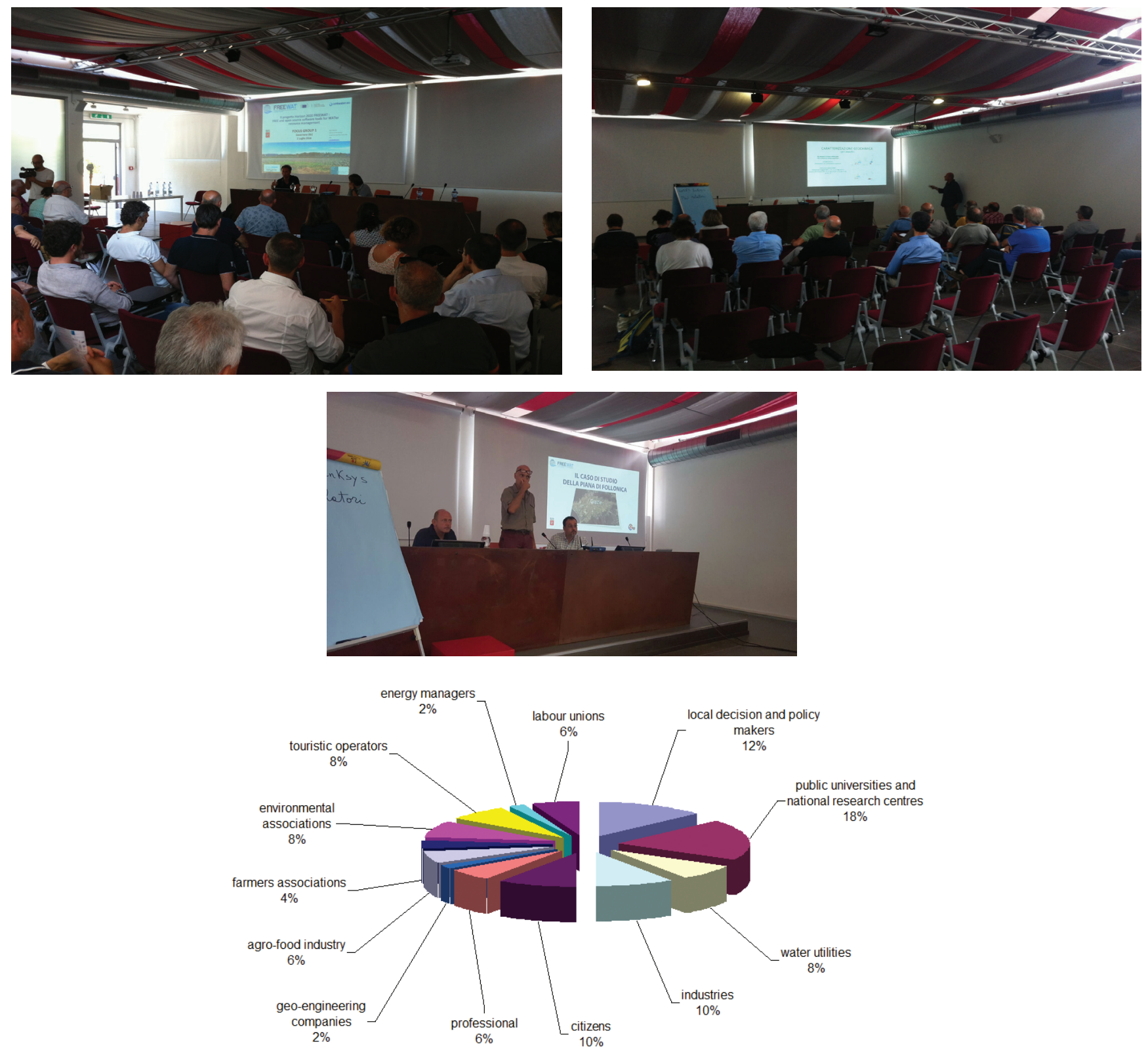

Fig. 7 - Pictures from Focus Group 1, 2 and main composition of the Focus Group, splitted in social and professional categories.

Fig. 7 - Fotografie dai Focus Group 1, 2 e principale composizione dei gruppi per categorie sociali e professionali. 
decision and policy makers, public universities and national research centres, water utilities and industries, citizens, geoengineering companies and professional, agro-food industry, farmers associations, environmental associations, touristic operators, energy managers and labour unions.

From the very first date of the focus groups the relevant themes in the field of water resource management for this area arose without any uncertainty and become more and more clear after each meeting. As underlined by the River Basin Management Plan, the most important water management problem emerged for the area is the gap in quantity of the water resource. The focus group highlighted three main aspects affecting water management of the study area. First of all, the industrial abstractions, mainly located in the central area of the basin, called the "Casone" area, headquarters of a very intense industrial activity. The second most relevant component perceived was the agricultural abstractions, even if there is a lack of real data of this kind. We had to estimate it considering the kind of crop for specific area declared to ARTEA (Agency for payment in agriculture of the Region of Tuscany) and the water demand for each type of these crops. The last component was the touristic increment of population, probably because is limited in time (only the summer season) and space (basically along the coast line), as in this area the population can grow up to ten times more during the summer (Dich. Amb. Comune di Follonica 2014). Under these three different aspects of the water management problem is implied the same economic issue: how to grant a constant and sustainable development of the economic activities in the coastal plain of Follonica and Scarlino. For this reason even the social representatives of the local stakeholders took part in the focus group through representatives of some labour unions.

\section{Focus Groups 4-6: targeting water management issues}

The objective identified during the first block of the focus groups matched with the problem of quantity outlined by the River Basin Management Plan for the water resource in this area. Thus, the second focus group block (from Focus group 4 to 6; figure 6) was based on the selection of the target measures, among those foreseen by the River Basin Management Plan under the section Programme of Measures (PoM).

In the RBMP the Follonica-Scarlino aquifer body shows a severe quantity gap (Fig. 8) and the target is the achievement

\section{Northern Apennines District :.: River Basin Management Plan}

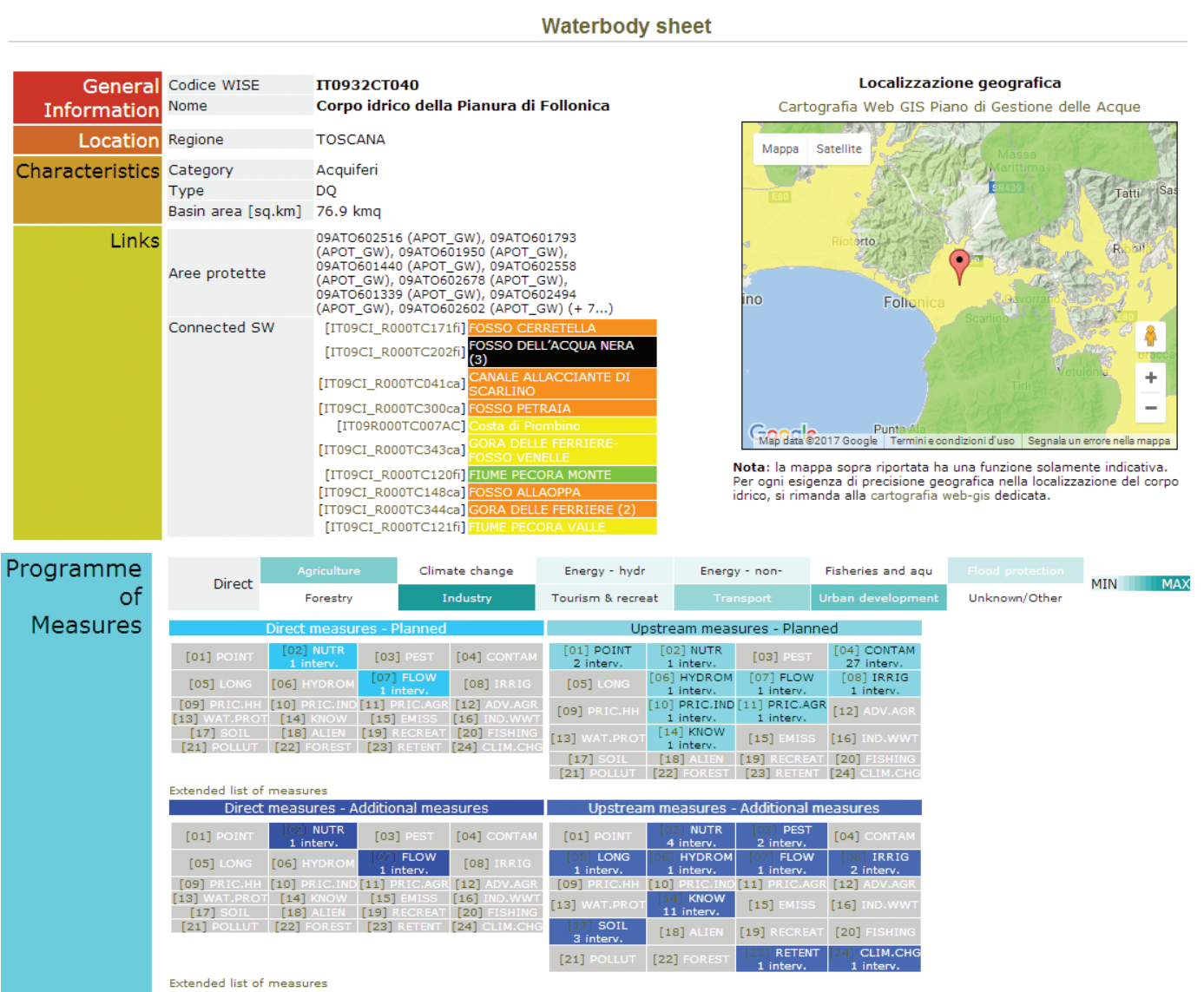

Fig. 8 - Water body sheet characteristics and Programme of measures (PoM) for the Follonica-Scarlino Aquifer. See River Basin Management Plan and Programme of Measures on-line source (2010) for the Northern Appenine District.

Fig. 8 - Caratteristiche dell'acquifero e Programma delle misure per l'acquifero Follonica-Scarlino. Vedi sito del Piano di Gestione delle acque del bacino per il Distretto dell'Appennino Settentrionale e Programma delle Misure (2010). 
of the state of "good" state in 2027. The Tuscan Authority for drinkable Water (AIT) made a plan in which it foresees the construction of a desalination plant and the doubling of the inflow water from Fiora river springs as a measure to improve the quantity of the water resource.

This kind of measure was proposed to the focus group by the project work team as one of the scenarios to investigate. Then, through some workgroup techniques, in particular SWOT analysis (Strengths, Weakness, Opportunities, Threats) (Hill \& Westbrook 1997) and a brainstorming, the stakeholders chose the other scenarios to be addressed by FREEWAT platform (Fig. 9).

\section{The scenarios}

During this block of focus group the community of the stakeholders chose two of the four scenarios that came out from the debate: the scenario number 0 and the scenario number 3 .

The scenarios discussed can be grouped depending on the type of approach:

- the scenario number 0 (desalination plant), 1 (well field displacement), 3 (mine water drainage reuse) were focused on the comparison of alternative water management strategies;

- the scenario number 2 (very hard summer drought conditions) was centred on possible future changes to the system.

The scenarios number 1 and 2 were not chosen by the participants of the focus group, so they were not implemented in FREEWAT model. A brief description of the four options to investigate is reported below.
Scenario 0: the construction of a desalination plant in order to improve the quantity of the resource. This scenario was based on the fulfilment of a part of the measures foreseen by the Programme of Measures in the RBMP for the Northern Apennines District.

Scenario 1: the removal of Salciaina wells field used for drinkable water supply and the building of a new well field far from the coastal area. The aim of this scenario is to demonstrate the utility of this project solution in reducing the phenomenon of saline intrusion.

Scenario 2: the simulation of an hypothetical future event of piezometric level in very hard summer drought conditions following a winter very poor of precipitations. This scenario was intended to identify the best solutions to address such a critical situation.

Scenario 3: the reuse of Gavorrano Mine drainage water for industrial purpose instead of withdrawals from wells located in the middle of the plain, in the industrial area of "Casone". The aim of this scenario is to demonstrate the utility of this project solution in reducing water table depression and seawater intrusion.

For the Scenario 0 the presence of a desalination plant should cause the closure of 11 wells used by local water utility (Acquedotto del Fiora) for water supply, for a total flow rate reduction of $0.47 \mathrm{Mm}^{3}$ per year (about $15 \mathrm{l} / \mathrm{s}$ ). Note that we have intentionally omitted all the aspects of economic evaluation (construction and operating costs, compared costbenefit analysis) because they were not part of the objectives of this study. These issues should be analyzed in case of a
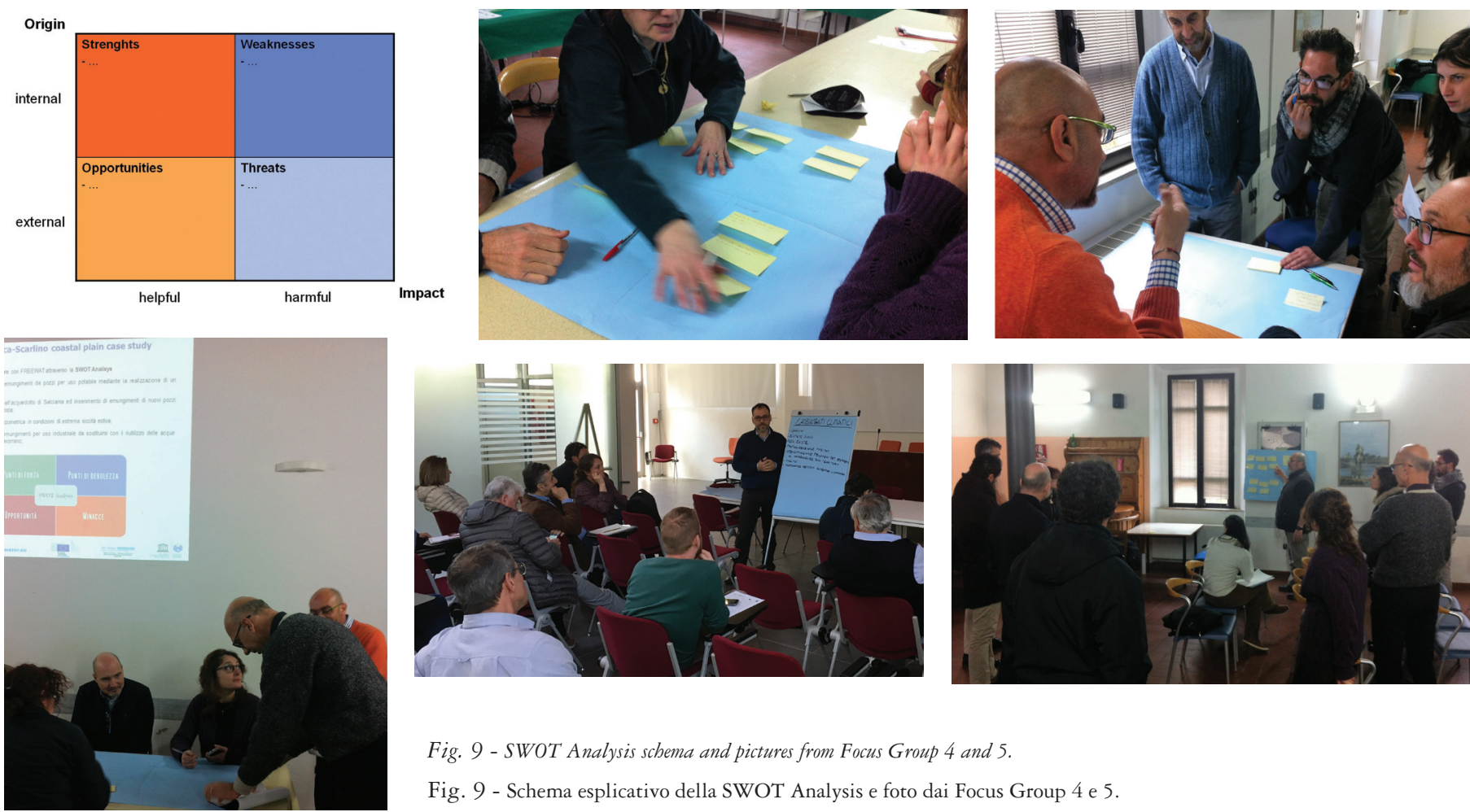

Fig. 9 - SWOT Analysis schema and pictures from Focus Group 4 and 5.

Fig. 9 - Schema esplicativo della SWOT Analysis e foto dai Focus Group 4 e 5. 
real application of this measure. The simulation allowed to compare, in steady-state and transient conditions, water budgets and water tables for the current state (water supply wells in use) and for the Scenario 0 (water supply wells off and desalination plant in operation at full capacity) (Fig. 10). The result of this scenario shows that a desalination plant replacing the well field for drinkable water supply has positive effects on the water table exploitation just around the well field.

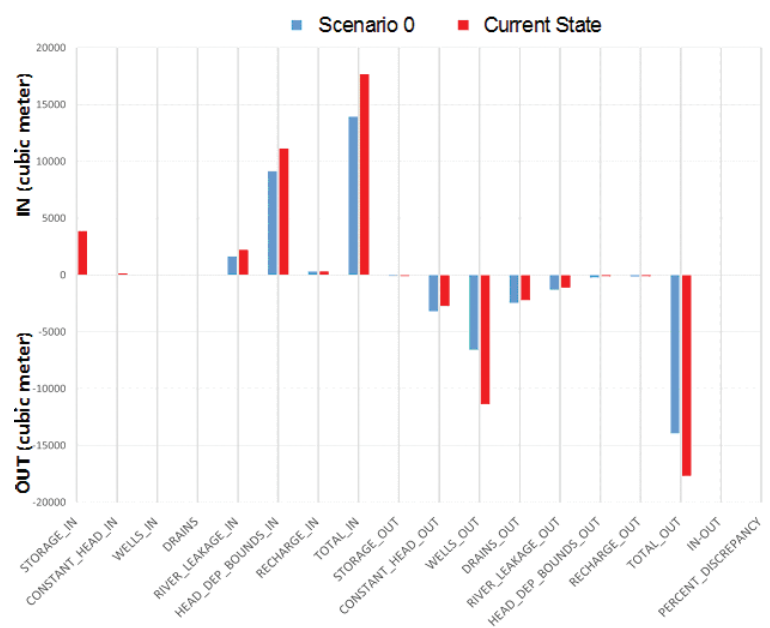

The scenario 3 deals with the reuse of Gavorrano mine drainage water reducing a lot, or even canceling, the industrial abstractions. The mine water (average total flow rate of 2.4 $\mathrm{Mm}^{3} / \mathrm{y}$, about $70 \mathrm{l} / \mathrm{s}$ ) is now pumped out in order to avoid the flooding of the tunnels that could charge the water with polluting compounds from the mining abandoned activities. Therefore, after a light treatment, this water is discharged into a drain that contributes to feed the aquifer system. The simulation showed that, even using an amount of $50 \%$ of the water drained from the mine, the aquifer budget is not negatively influenced and the minimum in water table surface at "Casone" disappears (green contour lines in figure 11). It is noteworthy that we did not address neither the issue of treating the water extracted from the mine to use it for industrial activities in the area, nor the purification methodology to be applied (in case of treatment) This topic was out of the scope of this case study. As for Scenario 0, the transient state model is difficult to calibrate because we have just one control point ("La Botte" automatic station in figure 5) with detailed and continuous measures of the piezometric level.

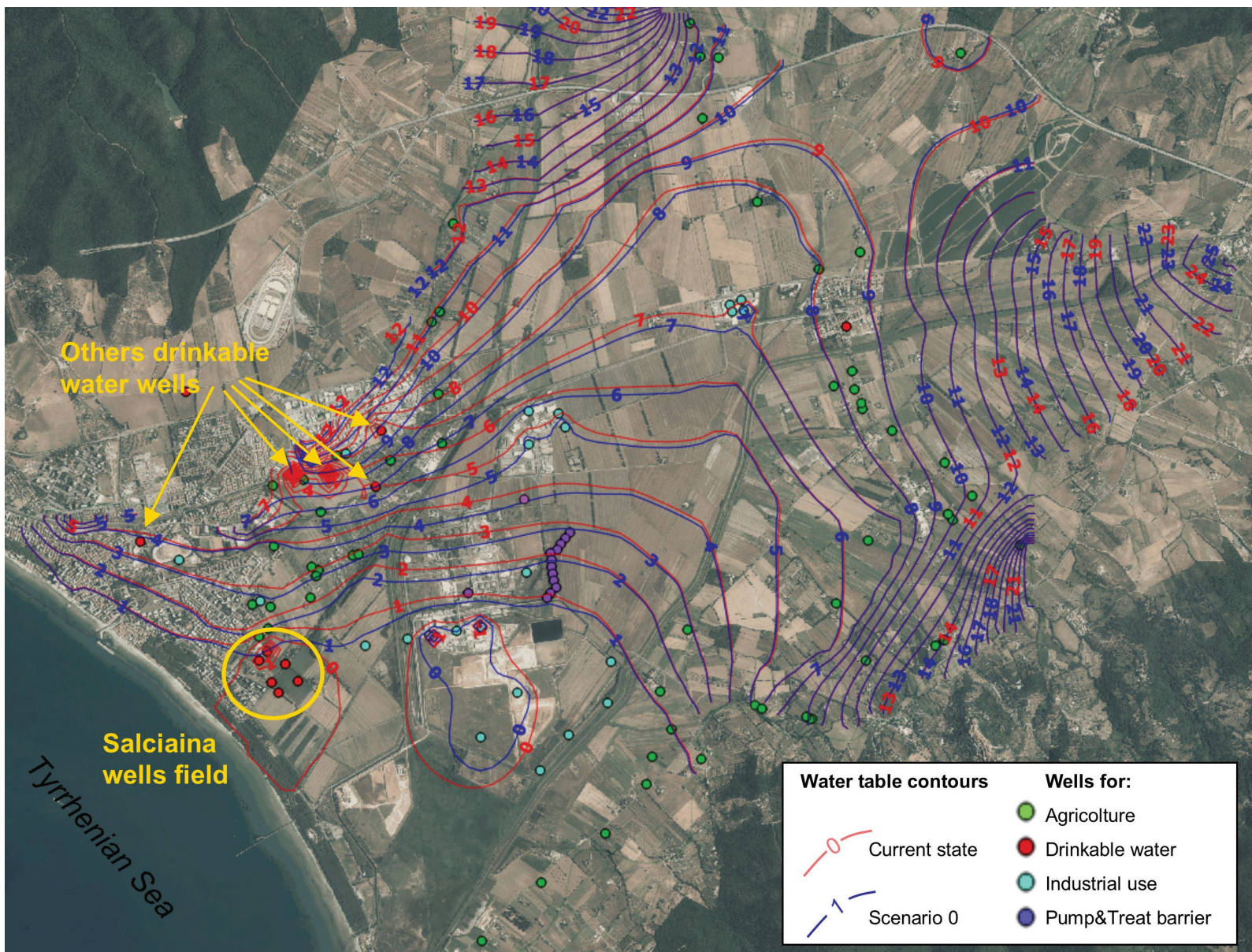

Fig. 10 - Water budget and comparison between two bydraulic beads simulated with FREEWAT for the scenario 0 in transient condition (low level condition sp12: July-September 2012).

Fig. 10 - Water budget e confronto tra due carichi idraulici simulati con FREEWAT per lo scenario 0 in stato transitorio (periodo di magra sp12: Luglio-Settembre 2012) 


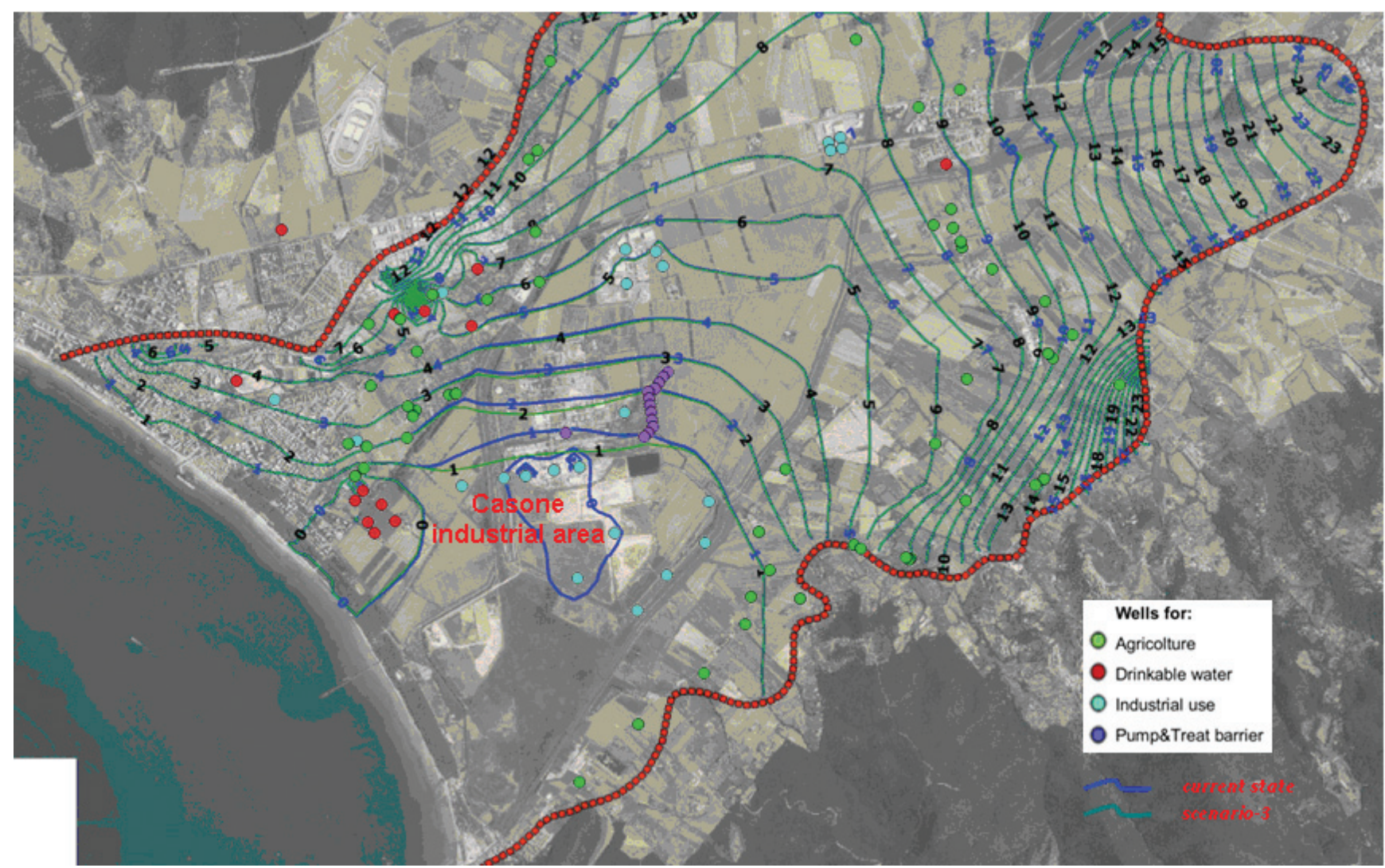

Fig. 11 - Comparison between two water tables simulated with FREEWAT for the scenario 3 in transient conditions (low level condition sp24 - July-September 2015 ) using 50\% of the mine drainage water for industrial purpose (total amount of the industrial area needs $=3524 \mathrm{~m}^{3} /$ day).

Fig. 11 - Confronto tra due superfici freatiche simulate con FREEWAT per lo scenario 3 in stato transitorio (condizioni di magra sp24 - Luglio-Settembre 2015) usando per scopi industriali il $50 \%$ delle acque estratte dalla miniera (totale del fabbisogno dell'area industriale $=3524 \mathrm{~m}^{3} / \mathrm{giorno}$ ).

\section{Focus Groups 7: results and Feedback from the stakeholders.}

During the last focus group results were summarized, collecting the participants' feedbacks on their experience taken from the case study.

The Scenario 0 highlighted that the measure proposed by the PoM it is not enough to improve significantly the quantity of basin water resource and reduce the saline intrusion problem because the biggest effect is on the reduction of withdrawals while minor effects are on the other components of the model (Fig. 10).

The modeling scenario 3 indicates that the analyzed measure could improve the quantity of basin water resource and could be useful to reduce the saline intrusion problem.

For both scenarios, better results could be achieved with other automatic station for continuous monitoring of the piezometric level, in order to enhance model calibration of the transient state.

The reuse of Gavorrano mine drainage water, in the opinion of the stakeholders, can be a very useful starting point to increase opportunities for the productive activities in the study area in a very responsible manner for the society and the environment. They indeed believe that this solution is capable of generating new "decent work" and long-lasting jobs. The United Nations Economic Social Council (UN 2006) and the International Labour Organization (ILO) define "decent work" as employment that "respects the fundamental rights of the human person as well as the rights of workers in terms of conditions of work safety and remuneration. [...] it respects the physical and mental integrity of the worker in the exercise of his/her employment". The stakeholders think that tools like FREEWAT are important to produce new work that is not only "decent" but also "green", since respecting the environment is the most successful way to make work sustainable and long-lasting. The stakeholders also noted the relevance of the results for the management of water resources in touristic season planning, while some engineers of local industries were interested in using FREEWAT platform as a modeling tool for their work starting from the numerical model produced by this case study for new model implementations.

\section{Conclusions and new challenges for the future of the study area}

The Follonica-Scarlino aquifer case study, run by Regione Toscana within the H2020-FREEWAT project, concerned mainly the experimental assessment of plans and measures in accordance with WFD 2000/60/CE. The River Basin Management Plan (RBMP) compiled by Northern Apennines District Authority indicates for this water body a severe quantity gap and the target is the achievement of a "good" state in 2027, through series of programmed measures. 
Two scenarios were simulated with FREEWAT platform, chosen through the participatory approach of a wide number of stakeholders: the construction of a desalination plant, as alternative source of drinkable water supply, and the re-use of Gavorrano Mine drainage for industrial purpose.

Both simulations have shown, the greater or lesser effectiveness of the proposed technical solutions for the achievement of the objectives set out in the RBMP. FREEWAT platform has therefore proved to be a powerful tool for water resources management with particular strength referring to: data collection and sharing, simulation of scenarios, support of planning and decision-making process, support in participatory and advisory procedures. Moreover no software licenses costs are needed.

FREEWAT project gave the opportunity to organize the huge amount of data collected for the Follonica-Scarlino aquifer basin and its participatory approach has proved to be crucial for a collaborative and synergic work with the stakeholders and among them. Moreover this kind of approach was useful:

- to reach more awareness about benefits of using numerical modeling;

- to enhance quality and quantity of data available for the numerical model;

- to grow up the importance of water resource monitoring and planning not only in emergency situations like draught or flood events;

- to produce Policy Briefs for decision makers involved in water resource management.

Important solicitations and new challenges derived also from the interaction with the stakeholders who stated as priority the translation of the case study to a real-world application in the study area, as soon as possible. A suggestion descending from this case study experience - and of crucial importance for any future application of participatory approach to numerical modeling of water resource - is to promote both the involvement of decision makers, who have to receive and apply these suggestions for a new kind of water management, and the involvement of the agriculture world of local stakeholders. Even if they are not so used to employ and understand tools for numerical modeling like FREEWAT their day-by-day use of water there is plenty of knowledge about this resource.

Acknowledgment: We want to warmly thank:

- Alessandra Casini, Parco Geominarario Colline Metallifere Gavorrano (Grosseto -Italy), for the kind hospitality and the incomparable logistic support;

- Giulio Masetti, Matia Menichini and Brunella Raco, CNR IGG Pisa, for the implementation of conceptual and numerical model of the Follonica-Scarlino aquifer system;

- Fabrizio Santini, Parco Geominarario Colline Metallifere Gavorrano (Grosseto -Italy), for the SWOT Analysis implementation support and for his unique logistic support;

- Sandra Elisei, Guido Lavorini, Annalena Puglisi and Maurizio Trevisani as members of the Regione Toscana FREEWAT Project Team.

This paper is presented within the framework of the project FREEWAT, which received funding from the European Union's Horizon 2020 research and innovation program under Grant Agreement n. 642224.

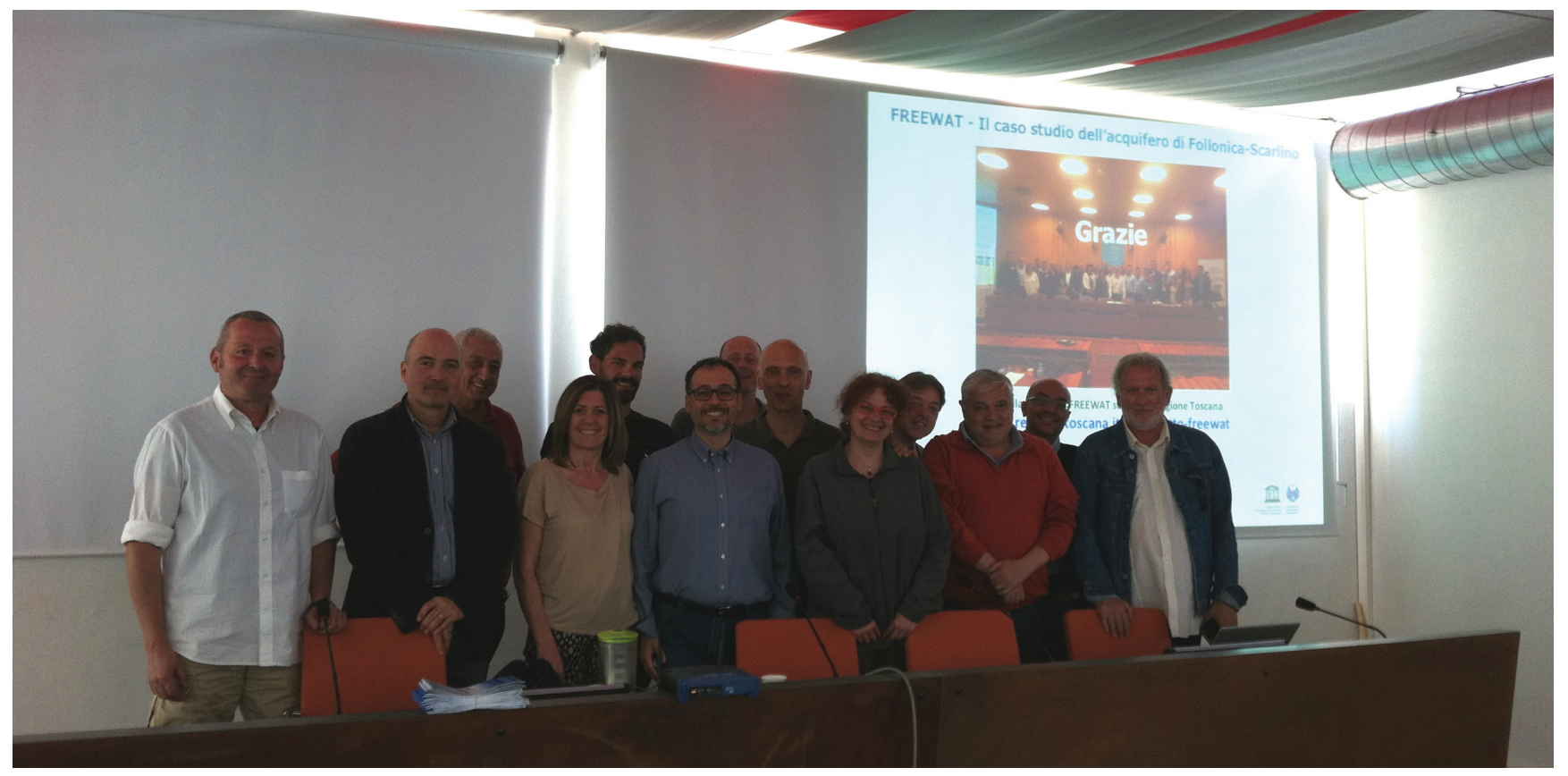

Fig. 11 - Picture from Focus Group 7.

Fig. 11 - Foto del Focus Group 7. 


\section{REFERENCES}

Comune di Follonica (2014) Dichiarazione ambientale EMAS "EMAS Environmental Statement of the Municipality of Follonica". Available from: www.comune.follonica.gr.it - last accessed 2017/04/10

Dalle Luche L. (2016) Dal modello concettuale al modello numerico: il caso di studio del sistema acquifero della Piana di FollonicaScarlino (GR, Toscana Meridionale). Tesi di Laurea Magistrale in Scienze e Tecnologie Geologiche. Università degli studi di Pisa, 117 pp. "From the conceptual model to the numerical model: the case study of the Follonica-Scarlino plain aquifer system (province of Grosseto, South Tuscany, Italy)". Degree thesis Geological Science and Technologies. University of Pisa, $117 p$ ).

Distretto Appennino Settentrionale (2016) Piano di Gestione delle Acque ex art 13, c. 7 Dir. 2000/60/CE e art. 117 D.Lgs 152/2006. Aggiornamento del Piano II Ciclo. Relazione di Piano. Available from: http://www.appenninosettentrionale.it/itc/?page_id=769last accessed 2017/03/17. "Northern Apennines District (2016) River Basin Management Plan ex art. 13 c. 7 Dir. 2000/60/CE and art. 117 D.Lgs 152/2006. $2^{\text {nd }}$ Cycle Plan update. Plan report. Available from: http://www.appenninosettentrionale.itlitcl?page_id=769 - last accessed 2017/03/17".

EU Water Framework Directive 2000/60/EC.

Harbaugh A. W. (2005). MODFLOW-2005, the U.S. Geological Survey modular ground-water model - the ground-water flow process. U.S. Geological Survey Techniques and Methods 6-A16, 253p.

Hill, T. \& R. Westbrook (1997 ) SWOT Analysis: It's Time for a Product Recall. - Long Range Planning.
Raco B., Buccianti A., Corongiu M., Lavorini G., Macera P., Manetti F., Mari R., Masetti G., Menichetti S., Nisi B., Protano G., Romanelli S. (2015) Geobasi: the geochemical Database of Tuscany Region (Italy). Acque sotterranee - Italian Journal of Groundwater $n^{\circ} 1 / 139$ : 7-18 - ISSN: 2280-6458.

River Basin Management Plan and Programme of Measures (PoM) on-line source (2010). Available from: http://www.appenninosettentrionale.it/eis/scheda_corpo_idrico_gen.php?cod=IT0932CT $040 \&$ tipocod $=$ wise $\&$ direttiva $=2000 \&$ lingua $=E N G-$ last accessed 2017/04/27.

Regione Toscana (2009) - Delibera di Giunta n. 939, 2009 October $26^{\text {th }}$ Individuazione e caratterizzazione dei corpi idrici della Toscana "Localization and characterization of the water tables of the Region of Tuscany". Available from: http://web.rete.toscana.it/attinew/?MIval= pag2a\&accesso=1 - last accessed 2017/03/17.

Turc L. (1954) Le bilan d'eaux des sols: relation entre les preécipitation et l'ecoulement. "The water balance of the soils: the relationship between rainfalls and surface runoff". Ann. Agron. 5, pp. 491-596.

United Nations COMMITTEE ON ECONOMIC, SOCIAL AND CULTURAL RIGHTS - THE RIGHT TO WORK, (2006) - General comment No. 18, Adopted on 24 November 2005, Article 6 of the International Covenant on Economic, Social and Cultural Rights. 